УДК 004.9:61

DOI: http://dx.doi.org/10.11603/mie.1996-1960.2016.1.5921

\title{
ІНФОРМАЦІЙНА МОДЕЛЬ ЛІКАРЯ ЗАГАЛЬНОЇ ПРАКТИКИ (СІМЕЙНОї МЕДИЦИНИ)
}

\author{
С. М. Злепко, С. В. Тимчик, Р. М. Вирозуб, О. Ю. Азархов ${ }^{1}$, Г. С. Лепьохіна \\ Вінницький національний технічний університет \\ ${ }^{1}$ Приазовський державний технічний університет \\ ${ }^{2}$ Скадовська центральна районна лікарня
}

\begin{abstract}
В роботі розглянуто розроблену авторами інформаційну модель сімейного лікаря. Показано їі новизну і функціональні можливості. Запропонована модель відповідає вимогам діючої посадової інструкції та критеріям Всесвітньої організації сімейних лікарів.
\end{abstract}

\section{INFORMATION MODEL OF A GENERAL PRACTITIONER (FAMILY MEDICINE)}

\author{
S. M. Zlepko, S. V. Tymchyk, R. M. Vyrozub, O. Yu. Azarhov, G. S. Lepohina \\ Vinnitsa National Technical University \\ Pryazovskyi State Technical University \\ Skadovsk Central District Hospital
}

In the paper the authors developed information model family doctor shows its innovation and functionality. The proposed model meets the requirements of the current job description and criteria World Organization of Family Doctors.

Вступ. За термінологією Всесвітньої організації сімейних лікарів (WONCA) сімейний лікар це фахівець, який надає первинну медико-санітарну допомогу (МД) всім членам сім'ї незалежно від віку, статі, характеру захворювання, з урахуванням психологічних, соціальних, культурних і особистих особливостей пацієнта та сім’ї.

Сімейні лікарі $\epsilon$ ключовою ланкою в системах охорони здоров'я більшості ринково орієнтованих держав. І це має раціональну основу: близько 80\% всіх проблем, пов'язаних зі здоров'ям, можна вирішити на первинному рівні.

Мета дослідження: розробка інформаційної моделі лікаря сімейної медицини.

Матеріал та методи дослідження. Для побудови інформаційної моделі функціонування лікаря загальної практики (сімейної медицини) необхідно визначити напрями сімейної медицини і функції, які має виконувати сімейний лікар.

До напрямів сімейної медицини слід відносити такі: моніторинг здоров'я; диспансеризація, проведення щеплень; профілактика захворювань; первинна експертиза тимчасової непрацездатності; цілодобова лікувально-діагностична допомога в межах, передбачених функціями сімейного лікаря: аналіз захворюваності; професійне зростання, контакт із сім'єю; санітарно-епідемічну роботу, організацію медичної допомоги; виконання обов'язків у межах посадової інструкції; сертифікат на роботу з медичною апаратурою. При цьому необхідно враховувати фактори, що впливають на роботу сімейного лікаря і залежать від пацієнта та лікаря, або мають організаційний характер, виконують буферні функції між сімейним лікарем та сім'єю через категорію «сімейні проблеми», які, з одного боку, зумовлені побутом членів сім’ї, а з іншого - генопрограмами, закладеними в кожного із членів сім'ї. 3 боку сімейної медицини, яка несе відповідальність за здоров'я сім'ї, альтернативою сімейним проблемам виступають сімейні стосунки, зумовлені сімейним підходом і сімейною практикою.

Враховуючи все вищезазначене, інформаційну модель функціонування лікаря загальної практики / сімейного лікаря можна уявити так (рис. 1).

Результати й обговорення. Розроблена інформаційна модель орієнтована на профілактичну спрямованість ЛЗПСЛ, заснована на сімейному принципі роботи при наданні ПМСД, має комплексний характер, що забезпечує СЛ такі можливості:

( С. М. Злепко, С. В. Тимчик, Р. М. Вирозуб, О. ІО. Азархов1, Г. С. Лепьохіна 


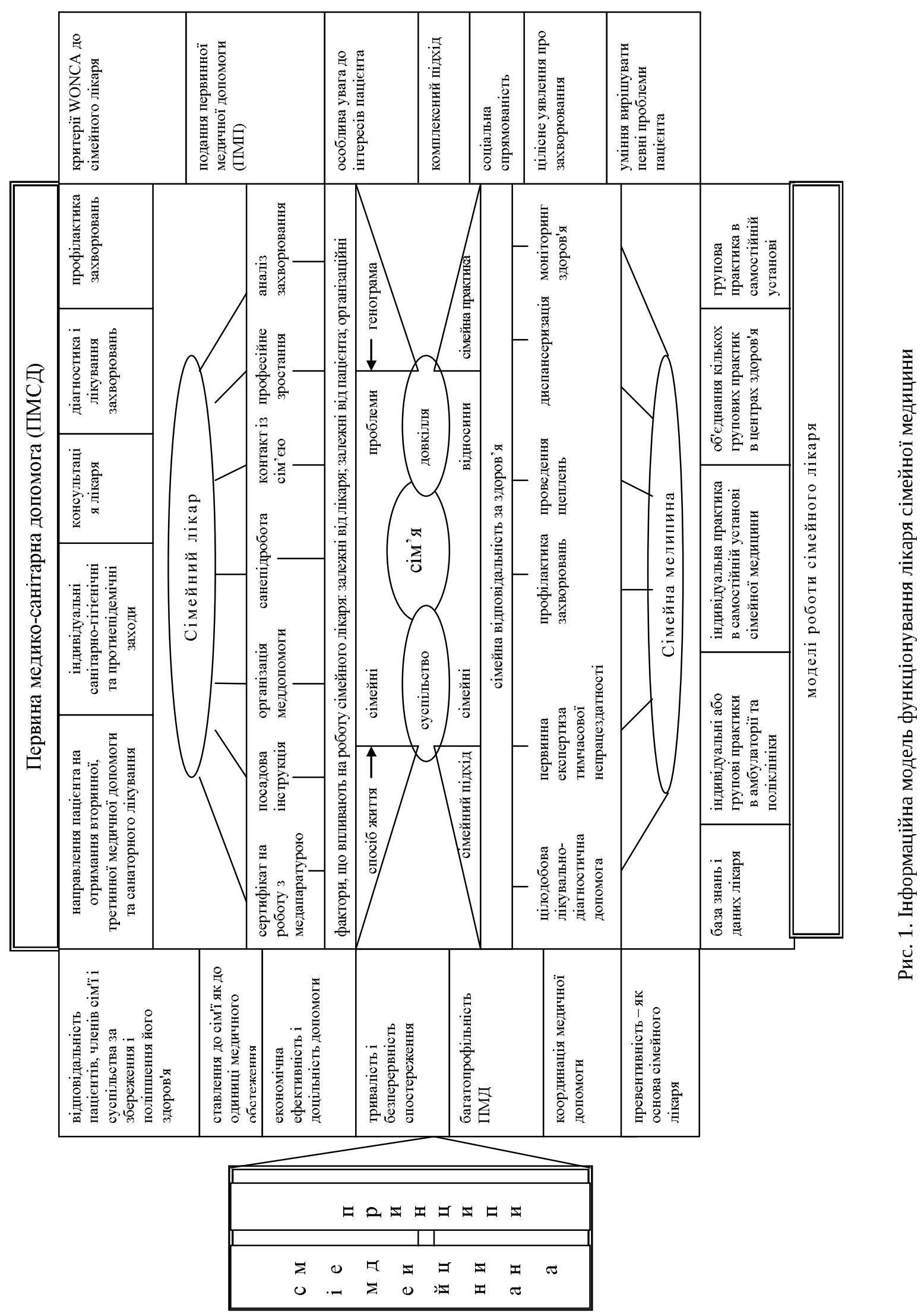


1. надання своєчасної кваліфікованої медичної допомоги членам сім'ї;

2. концентрацію уваги СЛ на складнодоступному контингенті молоді з поганою спадковістю та іншими факторами ризику;

3. виконувати функції сполучної ланки між сім'єю і закладом охорони здоров'я;

4. здійснювати комплексну оцінку здоров’я сім’ї, її репродуктивної функції, своєчасно виявляти фактори ризику хвороби у дітей та активно на них впливати.

Запропонована модель забезпечує сімейного лікаря знаннями і даними, що формують логічнозумовлену послідовність його дій при виконанні своїх професійних обов'язків за посадовою інструкцією, здійснюються згідно із принципами сімейної медицини, відповідають вимогам WONCA до сімейного лікаря, формалізовані у вигляді математичних та інформаційних моделей роботи сімейного лікаря.

Основу такої діяльності забезпечує база знань i даних, яка містить великий обсяг нормативних, довідкових, лікувальних, профілактичних даних та іншої інформації, функціонує під управлінням СУБД типу SQL-сервер і дає лікарю можливість оперативного отримання будь-якої інформації, пов'язаної із його професійною діяльністю.

Висновки. Перший досвід роботи лікарів сімейної медицини в пілотних регіонах проведення реформи показав значне зростання інформаційного навантаження на кожного з них. Впровадження комп'ютерної техніки та спеціалізованого програмного забезпечення в діяльність сімейного лікаря дасть можливість знизити інформаційне навантаження на лікаря. Створення на основі розробленої моделі сучасного автоматизованого робочого місця сімейного лікаря (АРМ СЛ), якими передбачається оснастити кабінети загальної практики, дасть можливість: покращити якість медичного обслуговування населення; забезпечить дотримання стандартів надання МД; забезпечить зворотний зв'язок «пацієнт - лікар», а також повноцінний моніторинг стану здоров'я населення. 